\title{
Effective Leadership for Good Governance in Nigeria; Addressing the Interface
}

\author{
Anyadike, Nkechi. O; Emeh, Ikechukwu E.J \\ Department of Public Administration, University of Nigeria Nsukka
}

\begin{abstract}
This paper studies the prospects of effective leadership in ensuring good governance in Nigeria. This is in recognition of the role of the concept of "effectiveness" in engendering productivity in a given polity. The underscoring of the effectivity of leadership on good governance is hinged on the highly professed problem of Nigeria by renowned scholars and political juggernauts, however, with the intent of exploring the missing link in achieving good governance through effective leadership.
\end{abstract}

\section{Introduction}

The concern and commitment to write a paper such as this where knowledge and experience on leadership and governance is explored is anchored on the belief that the ability of any government to meet the yearnings and aspirations of its entire citizenry and the international community both now and in the future depends largely on the ability, competence, loyalty, dedication and the capability of its leadership and governance apparatus. Suffice it however, that there have been several efforts at changing the lots of Nigerian through awareness and enlightenment packages. These efforts have taken the forms of Retreat for political office holders, top echelon of the civil service and administrative heads of Ministries/Extra-Ministerial Departments and Parastatals; Seminars and Conferences, Re-orientation Workshops for directorate level staff, in-house training, etc., but this paper aims at raising awareness among Nigerian leaders and followers on the need to reshape our leadership to ensure good governance.

In helping to achieve this magnanimous objective, this paper x-rays the concept of leadership and good governance; Nigerian leadership status and the need to reshape leadership for good governance while exploring the missing link, after which, the paper will conclude with recommendations which if religiously adhered to will take Nigeria to the much desired governance haven.

\section{Leadership and Good Governance}

The attainment of good governance is a function of effective leadership, especially when judging in the light of Onah's (2005) assertion that the attainment of organizational goals would be extremely difficult, if not impossible, if there were no specific individuals with the authority and responsibility to plan, organize, coordinate, lead and control activities. Therefore, the need for good leadership becomes unequivocal.

Leadership dwells in the realm of the people and their behaviour, hence in line with Ikpe's (2000) definition of leadership as the activity of influencing people to strive willingly for group objectives and Ademolekun (1986) leadership as an interpersonal influence exercised in a situation and directed through communication process toward the attainment of desired goals, we therefore assert that effective leadership is the ability to persuade others to seek defined objectives enthusiastically and efficiently.

While the debate on whether leaders are made or born persists, true leaders ignore such arguments and concentrate on developing the leadership qualities necessary for success; Qualities as adopted from Kouzes and Posner (n.d) honesty; forward-looking; competence; inspiring; and intelligence. Thus, one's ability to exhibit these five leadership qualities is strongly correlated with people's desire to follow one's lead, as exhibiting these traits will inspire confidence in one's leadership, and not exhibiting these traits or exhibiting the opposite will decrease one's leadership influence with those around you (http://www.leadership501.com/five-most-importantleadership-traits/27/). Afteral, John C Maxwell, in his 21 Irrefutable Laws of Leadership, sums up the definition of leadership thus: "leadership is influence - nothing more, nothing less" because it moves beyond the position while defining the leader, to looking at the ability of the leader to influence others - both those who would consider themselves followers, and those outside that circle. Indirectly, it also builds in on leadership character, since without maintaining integrity and trustworthiness, the capability to influence will disappear. Therefore, good leaders are made not born, hence whoever has the desire and will-power can become an effective leader 
because good leaders develop through a never ending process of self-study, education, training, and experience (Jago, 1982).

Therefore, leadership is the act of leading performed by a person authorized though appointment or election to do so. Leadership emerged because every society is either organized or seeks to be organized as the masses cannot lead hence the need to have a few people to lead (Ujo, 2001). For the purpose of this paper, a leader is a person who influences a group of people towards an effective and efficient result. It is dependent neither on title nor formal authority. Thus, Ogbonnia (2007) defines an effective leader "as an individual with the capacity to consistently succeed in a given condition and be viewed as meeting the expectations of an organization or society." This is because leaders are recognized by their capacity for caring for others, clear communication, and a commitment to persist, as individual who is appointed to a decision-making position has the right to command and enforce obedience by virtue of the authority of his position. However, he must possess adequate personal attributes to match his authority, because in the absence of sufficient personal competence, he may be confronted by an emergent leader who can challenge his role in the organization and reduce it to that of a figurehead.

On the other hand, the ability of any country to consistently improve its performance in terms of economic growth and development depends on good governance embedded in well structured and diligently implemented public policy.

Conceptually, governance has been identified as a good omen provided it accomplishes the desired end of the state defined in terms of justice, equity, protection of life and property, enhanced participation of citizens, observation, preservation and respect of the rule of law and improved living standard of the populace. Thus, governance is defined as the process that is employed to achieve the noble end of the state. It implies the art of leading a people within a given territory or a state; consisting of two essential elements of the state, namely the structure and procedure of the state.

For enhanced understanding of the concept of governance, the Farm House Dialogue (2000) defined governance as the exercise of political, economic and social authority to regulate human interaction for the well being of the society. It furthered that whereas good governance is a state of satisfactory fulfillment of expectations and the achievement of societal well being by the mandated authority, the opposite is bad governance.

It is in this regard that the World Bank (2002) viewed governance as, "the manner in which power is exercised in the management of a country's economic and social resources for development. The Bank further identified the following three key aspects of governance: the form of a political regime; the process by which authority is exercised in the management of a country's social and economic resources and the capacity of governance to design, formulate and implement policies and discharge functions. In line with the above, governance, is seen as the process of authoritative management of a country's resources through a well designed, formulated and implemented policies for the welfare of the people. The effort encompasses institutional and structural arrangements, decision making processes, policy formulation and implementation capacity, development of personnel, information flows and the nature and style of leadership within a political system because governance is largely about problem identification and solving; and the extent to which the society's problems are solved or not depends on how good or bad the governance is.

Bad governance according to the World Bank (1992) has many features, among which are: failure to make a clear separation between what is public and what is private, hence a tendency to divert public resources for private gain; failure to establish a predictable framework for law and in government's behaviour in a manner that is conducive to development, or arbitrariness in the application of rules and laws; excessive rules, regulations, licensing requirements, etc, which impede the functioning of markets and encourage rent-seeking; priorities that are inconsistent with development, thus, resulting in a misallocation of resources and excessively non-transparencies in decision-making. When these features occur together, they create an environment that is hostile to development hence the essence of government is to engender development. In such circumstances, the authority of governments over their peoples tends to be progressively eroded; and as such, bad governance represented by corruption, and lack of accountability and transparency, provides opportunities for the well connected elites and interest groups in the society to corner for themselves a sizeable proportion of the society's resources at the expense of the masses. Thus, bad governance is contrapuntal to a nation's socio-economic and political development (Obadan, 1998, cited in Ogundiya 2010). Thus, the attainment of good governance requires accountability, transparency, rule of law and human rights, responsiveness, a strong civil society, free press, social sanction and reward system, popular participation, efficient systems and structures. 


\section{Good Governance in Nigeria}

It is a glaring fact that despite her vast resources and huge potentialities, Nigeria remains grossly undeveloped as abject poverty, acute youth unemployment; heightened crime rate, poor health prospects and widespread malnourishment have been the main features of Nigeria's political economy (Ogundiya 2010). Hence the problem of development in Nigeria is a problem of governance; especially when defined in terms of the proper, fair and equitable allocation of resources for the achievement of the ends of the state, which is the promotion of the common good of the people. In lieu of Dudley seers opinion, inequality also looms large in Nigeria.

Unfortunately, Dickson had averred that one fundamental thing we lack in governance and government in Nigeria is the word "good" even when many Nigerians have identified good governance as the sine qua non for peace, progress, stability, free and fair elections. In fact it is viewed as the only passport to delivering the dividends of democracy. For the nation to work, we need good governance. In order to maximize our potentials, improve the general welfare of the Nigerian people and even development in geo-political terms, there must be good governance. Until good governance is viewed as the process of decision-making and the process by which decisions are implemented, we are still far off simply because the way and manner public persons deal with public institutions, conduct public affairs, manage public resources, are questionable, corrupt, and without due regard for the good of the people (Dickson, 2012).

\section{Leadership for Good Governance in Nigeria}

Good governance within the confines of a popular democracy should be anchored on two things- a constitution suited to the special needs and circumstances of Nigeria and leadership suited not only to the exigent needs of Nigeria, but the exactitudes of the people. Hence good governance requires no ordinary type of leadership as tolerance, breadth of outlook, intellectual comprehension, hard work, selfless devotion, statesmanship, a burning sense of mission are some of the virtues that are necessary to make a success in this nation. Unfortunately past administrations have lacked these virtues or at best have possessed one at the expense of the other and as such led them to groping in the dark on how to deliver good governance. The increasing fears is that today, with the legislature implicitly, involved, the current government is guilty of the same crime; as the current administration have refused to cultivate leadership qualities shown to have knacks to develop a mental magnitude, as clear as our problems are, and there seems a lack of ability in appreciating and grasping the salient details as well as most of the temporal and practical implications of a given situation or problem (Dickson, 2012).

Hence, the crop of leaders that have attained leadership position since independence in Nigeria had in one way or the other lacked vision and most of them have been engrossed with corrupt practices and political bickering leading to the enthronement of maladministration and mismanagement of public resources, which beget economic setbacks and abject poverty as a national heritage. This is based on the fact that the socio-economic and political development of any country depends largely on the ability of its leadership to facilitate, entrench and sustain good governance. Good governance seen as a manifestation of committed, patriotic and discipline leadership. In Nigeria's fifty-three years of independent existence, there is but little record of socio-economic development. This ugly trend is not unconnected with poor leadership as Achebe and others had asserted (Lawal, et al, 2012).

Thus, Professor Anezi Okoro, in his introductory remark as the chairman of Dialogue 33, an African Leadership Forum, examined the various leadership dynamics, complexities and contradictions that have transported African countries (Nigeria inclusive) from the misfortunes of colonial domination to the damnation of bad governance and the consequent misery that has become the lots of most Africans. African leaders, he said, have, through a complex mix of mismanagement, pandemic corruption, primitive greed and gross incompetence, comprehensively retarded the growth of their nations and peoples and relegated them to the lowest rungs of global economic ladder. He lamented the tragic irony of Africa's abject poverty in the midst of its often stated super-abundant natural and human resources. This he attributed partly to historical hangovers and subsequent neo-colonial manipulations, actively aided by the divisive internal forces deeply entrenched at the heart of many African societies in the face of which both leaders and the followers have remained lamentably helpless, and at times, criminally negligent (Farm House Dialogue, 2000).

\section{Addressing the Interface}

In addressing the interface, the identification of the missing links becomes imperative. Thus, Lawal \& Dare (2012) in discussing Leadership Debacle as the Bane of Good Governance in Nigeria identified Non-Adherence to the rule of law; Absence of development oriented leadership; lack of Accountability and Transparency; Electoral malpractices challenges; and Corruption as the missing links. Corroboratively, the major findings of 
the Farm house Dialogue's Africa Leadership Forum thirteen years was that corruption has remained an abiding problem in both the private and public sectors of the economy, thus, making it almost impossible for many Nigerians to provide selfless and transparent leadership. The effect is that this lack of essential public spirit has turned bad governance into something close to a normative pattern; hence there has been deliberate attempt by those in positions of authority to alienate the masses. This act is in stark violation of the palpable fact that leadership and governance require an active and qualitative interaction between the leaders and the led as a way of defining minimum standards required for developing society to provide checks and balances and to open up a communication channel between both sides.

In salvaging the situation, the need to identify strategies for the creation and nurturing of effective leadership as well as the provision of an enabling environment for good governance through the establishment of strong and efficient structures becomes imperative. This is in keeping with the trend of considering leadership in a global sense in order to appreciate the collective responsibility that individuals, groups, and institutions share in determining the pattern of leadership that are desirable in society.

Aside corruption, other factors that militate against good governance and effective leadership in Nigeria constitute moral or ethical issues which operate as retardant to the emergence of effective leadership and good governance when they are absent in a polity. These include, corruption, ethnocentrism, the politics of exclusion, discrimination, political opportunism, economic mismanagement, weak social institution, weak bureaucracy, lack of transparency, job insecurity and unemployment, nepotism, mediocrity, lack of patriotism and sycophancy, lack of national consensus, communication gap between the government and the governed, social political alienation, lack of respect for the rule of law, endemic poverty and low human development, poor population management strategies, flawed educational system, environmental degradation, intolerance, inconsistencies in government plans and lack of continuity etc. These have conspired to make the emergence of effective leadership and good governance difficult in Nigeria (farm House Dialogue, 2000).

\section{Recommendations}

We therefore conclude this paper with the following recommendations:

\section{Leadership with Honour and Followership with Guts, And Morals.}

As sad as it is, all Nigerian leaders have one thing in common, and it was neither compassion nor transparency. It is selfishness and wickedness; which is why they saw themselves as rulers of their people, not their leaders. Should they use their political powers to serve their people with vision, kindness, accountability, responsibility and transparency; should they serve selflessly and eschew ethnic partisanship and religious chauvinism; should they avoided self aggrandizement and delusion, Nigerian will been a better place to dwell in. Afteral. Behind every selfish politician, there is a dedicated leader; a quote that Abraham Lincoln left for all black African leaders, including his son.

But the leaders alone are not to be blamed as followers also have their fare share of the leadership problem and bad governance in Nigeria. This is why, it is usually said that the understanding or misunderstanding of the concept of leadership has been the blight and often the bane of many men at the top in Nigeria. Misunderstanding the concept of followership is the other side of the same coin of failure or collapse of the society.

Until both the leaders and followers, get their roles right, good governance will continue to elude us. This is because, tyranny and sycophancy are two evils which feed on and sustain each other, usually obtainable in a situation of leadership bereft of honour and followership bereft of guts, and morals leading to government of sycophants, because present day Nigerians faced with mismanagement of nation's economy by their own leaders have gone limp and dump; Each seeking safety in being accommodated in the public service or private sector for "a share of the national cake", not minding that there is no future in securing a share of cake instead of helping to bake more cakes for the future Nigerians (Farm House Dialogue 2000).

\section{Fix the Problem, not Blame}

No other country is so richly and diversely endowed like Nigeria with both human and materials resources, and as such, poverty in Nigeria cannot be blamed on inherent poverty of the country or an act of God. Nor can the distraction of blaming the European scramble for Africa and colonization for the poverty in Africa in general and Nigeria in particular, be tolerated any longer, because the same European invaders had scrambled for Asia earlier, and colonized various East Asia countries for longer periods. Today, many of those countries have yank off the bogey of colonial hang-over, and embraced mass education, social and economic development, 
industrialization and global commerce. These measures have given them much better quality of life indices, and earned them the respect of the world (Farm House Dialogue 2000).

Regrettably, some apologists of our failure and improvidence still blame the European invaders and colonial masters. To achieve effective leadership for good governance, we must forgive the Europeans and understand their tricks, then plan for ourselves and ensure that we make up for those years lost during their domination developmentally. In that way, it could be said that we are trying, instead of continuous apportioning blame rather than fixing our problem.

Developmentally, Nigeria has improved significantly over the years in all respects, but leadership. Dudley Seers' simple advice is check what is happening to unemployment, poverty and inequality. If all is not well with them, know that you are not developing no matter your GDP, but because Nigerian Leaders, who naturally are selfish, has refused to be dedicated to a course for which they were elected and as such are respected as such. A little dedication to the course of solving the problem of the people he is leading will make him examine to ascertain what is happening to unemployment, poverty and inequality. These factors are growing unchallenged in Nigeria while leaders are growing richer continuously.

\section{General Amnesty for all Nigeria Leaders (Past and Present)}

The test of any leadership or governance is on how it impacts on her economic advancement as it will be revealed on how the life of the people improves or deteriorates. Unfortunately, all that Nigerian leaders struggle for is the biggest share of the national cake. But suffice it here that there is no real safety in just ensuring "a share of the national cake, no matter the size" which will dwindle to vanishing point, if no input is made to replenish it by higher productivity in every sector. To those in various public offices, there is no real safety in indulging in graft and corruption in one's work place to "match" the graft and corruption orchestrated by those in the political leadership positions.

Consequently, the increased rate of unemployment in the country is because monies meant for the economy has been looted by the leaders and their cronies. But looting the monies is no longer our problem but the lost incurred in the investible income these monies could have generated and so an "amnesty package" for all corrupt government officials to return those stolen monies stashed outside the country for investment in the country is highly recommended. If any of them does not fancy investment, let same simply lodge such monies in any of the Nigerian banks so that Nigerians can access such monies at interest rates not above 5\%. By that act, the banks will instead of laying off their workers, employ more hands and people who are interested in entrepreneurship can get these monies as their capitals and start up their personal businesses. Afteral, it pays to be an employer than being an employee. By amnesty, I mean that these men who had looted the country on the course of their rulership/leadership, will not face the law so long as they brought all their monies back home and the international community shall confiscate any left after a stated period of time, while they are published worldwide as corrupt leaders and banned from active political life.

\section{Adherence to Research Recommendations by the Authorities}

Having established factually that the nature of governance in any given political system is determined by the quality of leadership in power, and that Nigeria, a nation endowed with natural and human resources still battles with crisis of leadership and governance after fifty-four years of independence, there is overwhelming need for research recommendations to be taken serious. For instance, the above identified maladies of the Nigerian economy has been there for decades and recommendations have highlighted the need to eschew them from our polity which was not paid heed to such that the obstinacy of the leaders was identified as the onefactor problem of Nigeria's development and advancement hence a country so blessed with both human and material resources, devoid of major crisis, natural and artificial, still occupies almost the lowest rung of the ladder in globally developmental perspective.

This assertion serves as the corollary of various fora, conferences, seminars and other brainstorming organizations whose heartfelt expectation is to see a Nigeria where unemployment has reduced beyond imagination, inequality suffering a calamitous end and poverty a thing of the past. The assertion is made with such confidence as seen in the faces of Nigerian leaders rendering campaign promises and those seen in the Nigerian developmental plans.

\section{Conclusion}

The above recommendations suffice that effective leadership requires a leader to seek the welfare of his people, and to guide them in achieving that objective. And because governance involves the exercise of authority, 
direction and control of a people, with the interest of the people in the front burner, good governance call for selfless, compassion, transparency and accountability, all of which are summary of the concept of dedication.

In all honesty, grabbling with the challenges of leadership and governance in Nigeria today is possible and achievable but rests on the preparedness of the leaders to bring to bear on our public conduct the principles of equity, justice and fairness, as well as judicious application of public resources, while putting the interest of the common man and the imperatives of building a nation that accommodates all, at the centre of our development objectives. The followers have major role to play in ensuring that the needed good governance through effective leadership is achieved by showing moral and guts instead of sycophancy and praise singing; all requiring dedication.

\section{References}

[1]. Dickson Charles (2011) Good Governance in Nigeria: The Tuwo and Soup Metaphor- http://saharareporters.com

[2]. Farm House Dialogue (2000) Leadership for Good Governance in Nigeria. Dialogue 33 by the Friedrich Naumann Foundation, for the Africa Leadership Forum.

[3]. Hoyle, John R. (1995) Leadership and Futuring: Making Visions Happen. Thousand Oaks, CA: Corwin Press, Inc., 1995

[4]. Jago, A. G. (1982). Leadership: Perspectives in theory and research. Management Science, 28(3), 315-336.

[5]. Kouzes, James M. \& Posner, Barry Z. (1987). The Leadership Challenge. San Francisco: Jossey-Bass.

[6]. Lawal, T, Imokhuede, K \& Johnson, I (2012) Governance Crisis and the Crisis of Leadership in Nigeria. International Journal of Academic Research in Business and Social Sciences. July 2012, Vol. 2, No. 7.

[7]. Obadan MI (1998). The State, Leadership, Governance and Economic Development, A Presidential Address Delivered at the Annual Conference of the Nigerian Economic Society, Kano. The National Centre for Economic Management and Administration (NCEMA).

[8]. Odunuga S (2003). "Failure of Governance and the Phenomenon of Conflict in Africa" in Oguejiofor J Obi (Ed.) Philosophy, Democracy and Responsible Governance in Africa, New Brunswick and London, Transaction Publishers pp. 153 -172.

[9]. Ogbonnia, SKC. (2007). Political Parties and Effective Leadership: A contingency Approach

[10]. Ogundiya, I.S (2010) Democracy and good governance: Nigeria's dilemma- African Journal of Political Science and International Relations Vol. 4(6), pp. 201-208, June 2010 http://www.academicjournals.org/ajpsir

[11]. Onah, R.C (2005) Public Administration. Nsukka, Great AP Express Publishers Limited.

[12]. Tolu Lawal \& Dare Owolabi (2012) Leadership Debacle: the Bane of Good Governance in Nigeria. Afro Asian Journal of Social Sciences Volume 3, No. 3.3 Quarter III 2012 ISSN: 2229 - 5313

[13]. Ujo, A. (2001). Understanding Public Administration, Kaduna Anyaotu Enterprises and Publishers (Nigeria). Ltd.

[14]. UNDP (1996). Report on the Workshop on Governance for Sustainable Human Development, MDGD, New York, April

[15]. World Bank (1992). Governance and Development. Washington: International Bank for Reconstruction and Development.

[16]. http://www.leadership501.com/five-most-important-leadership-traits/27/). 